organised jointly by the departments of surgery and of anatomy and developmental biology. The course is aimed at trainees from all surgical specialties. A third of the course will be taught and will provide an overview of the "new biology," with the aim of improving the level of scientific appreciation in surgery. The remainder of the course will be a research project done at the bench. Projects are offered in a wide range of science laboratories in the university and medical school.

The Association of Professors of Surgery has advised that every surgical trainee should undertake a period of full time research training, but it must be borne in mind that most surgeons will not subsequently perform laboratory research. This course offers an MSc in surgical science, and those with a primary motivation towards an academic career will be able to proceed to $\mathrm{PhD}$ registration. It is hoped that this type of programme will answer many of the criticisms of ill conceived and piecemeal research and provide a model for surgical training in the future.

D A MCGROUTHER

Department of Surgery,

Division of Plastic and Reconstructive Surgery,

University College London Medical School,

Rayne Institute,

London WC1E 6JJ

1 Smith R. Academic medicine: plenty of room at the top. $B M 7$ 1993;306:6. (2 January.)

\section{Colleges' concern}

Edror,-C J McCullough rightly draws attention to the part that the royal colleges might play in a reassessment of the present system of delivering health care.' It will come as no surprise to learn that colleges have serious concerns about the current problems - "overspent," "underfunded" hospitals indicating a flaw in either the underlying principles of health care or their implementation. These concerns have been expressed to the secretary of state, the chief medical officer, and the chief executive of the NHS collectively and independently, and the colleges have indicated their willingness-indeed, their wish-to work with the administration to address both the immediate issues (as a matter of urgency) and long term issues.

As to the conflict between consultants' ethical and contractual obligations, it is surely the case that because of the vulnerability of patients, and to maintain patients' trust, doctors must always put ethical considerations first. How that responsibility is best discharged can be decided only by the person concerned.

\section{Medical Royal Colleges and their \\ Faculties in the UK, \\ Royal College of Obstetricians \\ and Gynaecologists,}

1 McCullough CJ. Fundholding practices get preference. $B M \mathcal{F}$ 1993;306:141. (9 January.)

\section{Self monitoring of blood glucose}

EDITOR,-Robert Tattersall asks, "Should people with non-insulin dependent diabetes mellitus monitor their blood glucose concentrations?"' Although perhaps a case can be made for self monitoring by patients treated with insulin, there is no evidence to justify this expensive and uncomfortable practice for most people with non-insulin treated diabetes. It is true that home blood testing provides more accurate information than that available from urine tests, especially in patients with an abnormal renal threshold, and that it also provides information about everyday fluctuations.
These advantages cannot, however, be considered to be worth while unless they can be shown to lead to better glycaemic control or a reduction of long term complications of diabetes, or both.

Several studies of self monitoring in non-insulin dependent diabetes have now been carried out, ${ }^{2-5}$ but no difference has been found in glycaemic control between those who monitor their blood glucose concentrations and those who do not. I have just completed a randomised study of 24 patients receiving oral hypoglycaemic agents, in which I compared the glycaemic control (as indicated by monthly assay of fructosamine) of a group allocated to self monitoring of blood glucose and a similar group who tested their urine. There was no significant difference in glycaemic control between the two groups during the six month trial.

Despite the discomfort of frequent finger pricking there is a degree of fascination associated with blood letting, ${ }^{\circ}$ and research suggests that most patients prefer blood testing to urine testing. ${ }^{7-10}$ But every unnecessary home blood test wastes $26 \mathrm{p}$ of scarce NHS resources (compared with $4 \mathrm{p}$ for a urine testing strip), and if each of Britain's 500000 non-insulin dependent diabetic patients carries out several tests a week the cost implications are enormous.

As a basis for adjustments to treatment results of self monitoring have now been superseded by the glycated haemoglobin concentration or results of fructosamine assays. Therefore, if self monitoring of blood glucose concentrations does not influence either treatment or glycaemic control its value is limited in non-insulin treated diabetes. A policy on home monitoring for this large group of patients should recognise that self monitoring is no longer the principal means of assessing glycaemic control but is, rather, a tool that can offer reassurance or warn of problems during the intervals between measurements of longer term control.

East Cornwall Hospital,

MARILYN GALLICHAN

Bodmin,

Cornwall PL31 2EN

1 Tattersall R. Self monitoring of blood glucose concentrations by non-insulin dependent diabetic patients. BMf 1992;305: 1171-2. (14 November.)

2 Wing RR, Epstein LH, Nowalk MP, Scott N, Koeske R, Hagg $\mathrm{S}$. Does self-monitoring of blood glucose levels improve dietary compliance for obese patients with type 2 diabetes? Am F Med 1986;81:830-6.

3 Newman WP, Laqua D, Engelbrecht D. Impact of glucose selfmonitoring on glycohemoglobin values in a veteran population. Arch Intern Med 1990;150:107-10.

4 Allen BT, DeLong ER, Feussner JR. Impact of glucose self-monitoring on non-insulin-treated patients with type 2 diabetes mellitus. Diabetes Care 1990;13:1044-50.

5 Forbonne A, Billaut B, Acosta M, Percheron C, Varenne P, Besse $\mathrm{A}$, et al. Is glucose self-monitoring beneficial in nonBesse $\mathrm{A}$, et al. Is glucose self-monitoring beneficial in non-
insulin treated diabetic patients? Results of a randomised insulin treated diabetic patients? Results of a
comparative trial. Diabetes Metab 1989;25:255-60.

6 Baum JD. Home-monitoring of diabetic control. Arch Dis Child 1981;56:897-9.

7 Sonksen PH, Judd SL, Lowy C. Home-monitoring of blood glucose. Lancet 1978;1:732-5.

8 Worth R, Home PD, Johnston DG, Anderson J, Ashworth L, Burrin JM, et al. Intensive education improves glycaemic control in insulin-dependent diabetes without further advantage from home blood glucose monitoring: results of a controlled trial. BMF 1982;285:1233-40.

9 Cohen M, Zimmet P. Self-monitoring of blood glucose levels in non-insulin dependent diabetes mellitus. Med f Aust 1983;2: non-insulin $377-80$.

10 Martin BJ, Young RE, Kesson CM. Home-monitoring of blood glucose in elderly non-insulin dependent diabetics. Practical Diabetes 1986;3:37.

EDIToR,-Lesley V Campbell and colleagues' and Robert Tattersall ${ }^{2}$ raise doubts about the usefulness of blood glucose monitoring strips in diabetes mellitus. We are also concerned about the reliance placed on these tests but in a different context. We have seen three cases of hyperosmolar hyperglycaemic deterioration of diabetes (two purely non-ketotic and one with a degree of ketoacidosis) and observed a discrepancy between the readings obtained with blood glucose strips (Ames strip plus a digital meter in case 1, BM-Test-1-44 strips in cases 2 and 3) and the laboratory glucose measurements.

Case 1-A man aged 84, not known to be diabetic, presented with confusion, cough, and anorexia. On examination he was dehydrated with a rapid pulse and slight tachypnoea. Glucose estimation by digital meter was $15.5 \mathrm{mmol} / \mathrm{l}$, but the laboratory measurement of $53 \mathrm{mmol} / \mathrm{l}$ suggested non-ketotic hyperosmolar hyperglycaemia. The patient died of thromboembolic complications.

Case 2-A woman of 85 with diabetes controlled by diet presented to the accident and emergency department and gave a history of loss of independence over two weeks and a fall. Her grazes were dressed, and a blood glucose concentration of $10 \mathrm{mmol} / \mathrm{l}$ was recorded with a BM strip. Examination otherwise was unremarkable. She was admitted for mobilisation, but tests requested the next morning on samples taken on the evening of admission showed a serum glucose concentration of $56.1 \mathrm{mmol} / \mathrm{l}$. The patient died of thromboembolic complications.

Case 3-An insulin dependent diabetic woman aged 74 gave a history of nausea for one week and poor diabetic control. A district nurse checked her blood glucose concentration with BM strips at home; it varied between 17 and $44 \mathrm{mmol} / \mathrm{l}$. The concentration obtained with a BM strip in the accident and emergency department was $17 \mathrm{mmol} / \mathrm{l}$, but the laboratory measurement was $82 \mathrm{mmol} / \mathrm{l}$. She had some ketoacidosis and responded to conventional treatment.

Non-ketotic hyperosmolar hyperglycaemia is uncommon and easily missed. It tends to present in elderly people, who may not be known to be diabetic. There is frequently a vague history, and they can appear surprisingly well, without the obvious dehydration and air hunger of younger ketoacidotic patients. Diagnosis can be delayed if too much reliance is placed on a blood glucose strip. These test strips should be used only for monitoring and not for making executive decisions.

The paradoxically low reading in hyperosmolar states despite good technique is highlighted in the datasheet supplied with the BM-Test-1-44 (though not mentioned in the Ames sheet) but is not generally recognised or taught. Its cause is not known (personal communication, Boehringer Mannheim UK (Diagnostics and Biomedicals), 1992), though the strips use a glucose oxidase reaction different from the hexokinase reaction of laboratory machines.

RICHARD DEAN JENKINS ASHRAF BAKHAT

Department of Medicine,

Bury General Hospital,

1 Campbell LV, Ashwell SM, Borkman M, Chisholm DJ. White coat hyperglycaemia: disparity between diabetes clinic and home blood glucose concentrations. BMF 1992;305:1194-6. (14 November.)

2 Tattersall R. Self monitoring of blood glucose concentrations by non-insulin dependent diabetic patients. BMF 1992;305: 1171-2. (14 November.)

\section{Paget's disease of bone}

EdiroR,-Roger Smith suggests that Paget's disease might be due to infection with a viral agent early in life.' Although this might well be the case, other explanations need to be considered. Familial clustering is well recognised in Paget's disease, with evidence of HLA linkage in some families and a greatly increased prevalence of the disease in first degree relatives of patients. ${ }^{2}$ The unusual geographical distribution is equally compatible with a genetic component. Paget's disease, while most common in western Europeans, also occurs frequently in their descendants in Australia and South Africa, where it is rare in the indigenous population. ${ }^{3}$ What could the mechanism of genetic Paget's disease be? 
Some parallels can be drawn with certain hereditary tumour syndromes such as multiple endocrine neoplasia. Both are characterised by a focal or multifocal pattern of distribution, abnormal cellular proliferation, and a genetic component. The hereditary tumour syndromes are thought to result from an inherited mutation in one allele of a tumour suppresser gene and an acquired mutation in the other allele. ${ }^{4}$

Almost 20 years have elapsed since Rebel first noted "virus-like" particles in pagetic osteoclasts, but the identity of these structures remains unclear and they are not specific to Paget's disease. Immunohistochemical and in situ hybridisation studies have yielded conflicting results, since at different times evidence has been presented to suggest that antigens or nucleic acids from measles virus, respiratory syncytial virus, or canine distemper virus might be present in pagetic tissue or cultured cells ${ }^{67}$ but no virus has been isolated from affected tissue. Several groups have now used the polymerase chain reaction to try to recover paramyxovirus sequences from pagetic bone. Colleagues and I found no evidence of measles virus, canine distemper virus, respiratory syncytial virus, or related paramyxoviruses in RNA extracted from pagetic tissue, ${ }^{8}$ and $M$ Birch et al recently reported similar findings. ${ }^{9}$ Though canine distemper virus transcripts (and in one case measles virus also) have been isolated from pagetic tissue, ${ }^{10}$ these data must be interpreted with caution in view of the possibility of external contamination, since the same group had previously worked with probes to both viruses during earlier in situ hybridisation studies. ${ }^{7}$ Finally, D Roodman et al recently reported finding measles virus transcripts in cells derived from cultured pagetic bone. ${ }^{9}$ These contradictory data could perhaps be explained by different viruses having a role in different geographical areas.

The powerful molecular techniques now available should soon result in great advances in our understanding of Paget's disease. ${ }^{7-10}$ An important immediate issue is to confirm whether paramyxovirus sequences can consistently be isolated from pagetic tissue and, if so, to determine whether their presence is disease specific.

STUART H RALSTON

Department of Medicine and Therapeutics,

Aberdeen AB9 2ZD

Smith R. Paget's disease of bone, $B M 7$ 1992;305:1379-80. (5 December.)

2 Siris ES, Ottman R, Flaster E, Kelsey Л. Familial aggregation of Paget's disease of bone. $\mathcal{F}$ Bone Miner Res 1992;6:495-500.

3 Gardner MJ, Guyer PB, Barker DJP. Radiological prevalence of Paget's disease of bone in British migrants to Australia. BMJ 1978;i:1655-7.

Knudson AG. Hereditary cancer, oncogenes and anti-oncogenes. Cancer Res 1985;45:1437-43.

Kanis JA. Pathophysiology and treatment of Paget's disease of bone. London: Martin Dunitz, 1992:1-293.

Mills BG, Singer FR. Critical evaluation of viral antigen data in Paget's disease of bone. Clin Orhop 1987;217:16-25.

7 Gordon MT, Anderson DC, Sharpe PT. Canine distemper virus localised in bone cells of patients with Paget's disease. Bone 1991;12:195-201.

8 Ralston SH, DiGiovine FS, Gallacher SJ, Boyle IT, Duff GW. Failure to detect paramyxovirus sequences in Paget's disease of bone using the polymerase chain reaction. $\mathcal{f}$ Bone Miner Res 1991;6:1243-8.

9 Selby $P$, ed. Proceedings of the first international symposium on Paget's disease of bone. Semin Arthritis Rheum (in press).

10 Gordon MT, Mee AP, Anderson DC, Sharpe PT. Canine distemper transcripts sequenced from pagetic bone. Bone Miner 1992;19:159-74

EDIToR,-Roger Smith underestimates the contribution that biochemical markers of bone resorption can make to the diagnosis and monitoring of Paget's disease.' Though urinary hydroxyproline and alkaline phosphatase are useful markers of bone resorption and synthesis, respectively, they are rather non-specific. Though no good new assays exist to supplement assays of alkaline phosphatase to assess bone formation, more specific markers are becoming available for bone resorp- tion. Pyridinoline (also known as hydroxylysyl pyridinoline) and deoxypyrolidine (also known as lysyl-proline) are not further metabolised, thus providing a better index of resorption than hydroxyproline, which also has the disadvantage that it is found in skin as well as bone.

Pyridinoline and deoxypyrolidine are found in collagens I, II, III, and IX, so both are found in extracellular matrix collagen crosslinks, while deoxypyrolidine is more common than pyridinoline in type I bone collagen crosslinks: the ratio of pyridinoline:deoxypyrolidine is $3.5: 1$ in bone collagen as opposed to $10: 1$ in other collagens. ${ }^{23}$ Released as a result of bone degradation, these markers can be measured either singly or together (to derive a pyridinoline:deoxypyrolidine ratio) by high performance liquid chromatography with fluorescene detection in 24 hour urine specimens and correlate well with rates of bone resorption.

Department of Chemical Pathology,

Charing Cross and Westminster Medical School,

Westminster Hospital

London SWIP 2AR

Smith R. Paget's disease of bone. BMF 1992;305:1379-80. 5 December.)

2 Eyre D. New markers of bone resorption. 7 Clin Endocrinol Metab 1992;74:470A-C.

3 Demers LM. New biochemical marker for bone disease: is it a breakthrough? Clin Chem 1992;38:2169-70.

\section{Getting it right}

EDITOR,-Helen Zeitlin is wrong in claiming that my article about her reinstatement was unjust and incorrect.' She has misinterpreted an indirect quote from evidence given on behalf of the health authority as a statement of fact by me. She knows that I am well aware that the 20 complaints referred to in that evidence were "unsubstantiated and had not even materialised," since I have covered her case in detail since the beginning. In the paragraph of which she complains I was briefly putting each side's case as outlined to the inquiry. Surely she is not suggesting that only her side of the case should have been put.

London NW1 7EG

CLARE DYER

1 Zeitlin H. Whistle blowing. BMJ 1993;306:210. (16 January.)

\section{Part time working and job sharing}

EDITOR,-J E Morrell and A J Roberts warn of the difficulties of part time senior registrar training. ${ }^{\prime}$ These are well illustrated by my own case. Working full time, I completed my general professional training, gained the MRCP, and undertook research. When I first applied for part time training in September 1984 I was interviewed within two weeks of the birth of my first child. There was only one post for part time senior registrar training in general medicine in the whole country, and I was not successful.

The next year only one post was available, and again I failed. My research post had been extended by my working part time, but in 1986 funding ran out. I had an MD and had had several articles published, and I was totally demoralised, feeling better qualified than some colleagues in full time senior registrar posts. Fortunately, the postgraduate dean organised a part time medical registrar post. In 1987 my application was successful, although there was only one post. I understand that the next year three posts were available.

Manpower approval was granted in January 1987. The educational programme was submitted, but the college did not visit until October. Its report was sent to my supervisors in February 1988, and after a few minor changes the college's final approval was received in May. Wessex region would not recognise me as a senior registrar until the college's approval had been received. I had two manpower extensions. The senior registra contract arrived dated May 1988, and a six month battle ensued to get it backdated to January 1987 . I was not a pioneer of part time senior registrar training in Wessex: several people were already in post.

Success in part time senior registrar training requires tremendous personal commitment, a sympathetic supervisor, and a helpful postgraduate dean. I was fortunate, yet I can recall that during my earliest discussions there was considerable concern about how a consultant appointment committee might view part time training. In my case, I am pleased to say, it was regarded in the same light as full time training. As Morrell and Roberts say, the experience is an invaluable education for the battles in the NHS as a consultant.

East Herts NHS Trust,

WENDY GATLING

Welwyn Garden City AL7 4HQ

1 Morrell JE, Roberts AJ. How to make an application for part time senior registrar training. BMF 1992;305:1411-3. (5 December.)

EDITOR,-Graham Thornicroft and Geraldine Strathdee discuss their experience of sharing a consultant post.' We have job shared for two years in several senior house officer posts in different specialties as part of our own scheme for vocational training for general practice. We have found it to be the ideal way of combining pursuit of a career in medicine with bringing up a family.

There is considerable difficulty in getting shortlisted when job sharing, and consequently we have found that job applications need meticulous planning. We submit our CVs with a joint covering letter explaining about job sharing, our reasons for choosing it, and how we would apply it to the advertised post. Most consultants have never experienced job sharing and have preconceived worries about its possible ramifications. We therefore believe that it is important to meet as many as possible, if not all, of the consultants before shortlisting, preferably together for a show of unity. Before the interview it is important to discuss the duties of the post with the present incumbents, paying particular attention to rotas and the timetabling of commitments such as ward rounds, on take days, and postgraduate meetings. It is then possible to decide how to split the hours of the job optimally while still maintaining as much continuity as possible.

We have always been interviewed simultaneously, which can be advantageous: over the years we have worked out quite a double act. Questioning invariably centres on our domestic arrangements rather than our abilities: we both have young children and share a nanny. For holidays we fall in with the wishes of particular consultants. It is generally mutually convenient if we take our holidays together as a block (it also enables us to give the nanny time off). Finally, interviewers are often hesitant to broach the question of one partner wishing to resign, so at interview we raise the issue and offer reassurance that should it ever occur the remaining partner would either also resign or take on the post full time.

Like Thornicroft and Strathdee, we emphasise the importance of trust and respect between the partners. We believe that our strength comes from our friendship and having similar priorities in life. Job sharing is not for the faint hearted: it demands complete commitment. To work effectively it needs the right partners and considerable organisation and communication. It is still a novel concept, and potential job sharers should be aware that they will be breaking new ground and that their 